\title{
Erratum to: Assessing the Power of China: Insights from the Conceptual Thinking about Power
}

\author{
Richard Q. Turcsanyi ${ }^{1,2}$
}

Published online: 9 August 2017

(C) Journal of Chinese Political Science/Association of Chinese Political Studies 2017

\section{Erratum to: J OF CHIN POLIT SCI https://doi.org/10.1007/s11366-017-9499-2}

The original version of the article unfortunately contained mistakes. In Table 1, the data "institutional setting" was seen twice in the Structural/international level. The correct information and presentation of Table 1 is given below:

Table 1 Levels and areas of sources of power

\begin{tabular}{lll}
\hline State/government level: & Structural/international level: & Societal level: \\
\hline Military & Institutional setting & Soft power \\
Economy & Geopolitical position & Domestic legitimacy \\
National performance & Geo-economical position & \\
\hline
\end{tabular}

Source: Author's design

The online version of the original article can be found at http://dx.doi.org/10.1007/s11366-017-9499-2

Richard Q. Turcsanyi

richard.turcsanyi@mendelu.cz

1 Department of Territorial Studies, Mendel University, Brno, Czech Republic

2 Institute of International Relations, Prague, Czech Republic 